\title{
Immediate Moderate Intensity Treadmill Exercise After Restraint Stress Induced ERK-mediated Anxiety and Depression
}

\author{
Heon Seok \\ Department of Biomedical Science, College of Science and Engineering, Jungwon University, Goesan, Korea
}

\begin{abstract}
Received: January 3, 2018

Accepted: January 20, 2018

Published online: January 31, 2018

Keywords:

Anxiety

Exercise

Extracellular signal-regulated kinase Depression

Stress
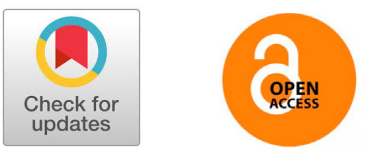

PURPOSE Chronic stress cause physical and mental function disorders such as anxiety and depression. One of the effective ways to relieve this stress is regular moderate intensity exercise. However effect of exact role of moderate intensity exercise on physical and mental function is not clear. This study aim to investigate the effect of immediate moderate intensity exercise after stress on anxiety, depression-like behavior and motor ability.

METHODS Six-week-old male wister rat were divided into three group which were control(CT) group, restraint stress (RS) group and treadmill exercise after restraint stress (EX) group. RS and EX group were subjected to restraint stress ( $1 \mathrm{~h} /$ day) for 5 days, while CT group were stay in normal condition. Immediate after restraint stress, EX group were subjected to treadmill-running ( $30 \mathrm{~min} /$ day) for 5 days immediate after restraint stress. Free moving tests and open field tests were used to analyze behavior and athletic competence such as anxiety and depression, and phosphorylation levels of ERK were assessed using western blotting of the brain hippocampus.

RESULTS In free moving test, freezing time of EX group were increased compared to RS group $(p<.05)$ and CT group $(p<.05)$. On the other hand, Velocity of EX group were decreased compared to RS group $(p<.05)$ and CT group $(p<.05)$. In open field test, velocity, distance and frequency in center of RS group were lower than CT group $(p<.05)$ and EX group were lower than ST group $(p<.01)$. Phosphorylation of ERK were increased on EX group.

CONCLUSIONS Immediate moderate intensity treadmill exercise after restraint stress increased anxiety and depression-like behavior and decreased motor ability. Furthermore, the activity of ERK protein associated with stress and depression was increased by immediate exercise after stress. The results suggest that immediate exercise after stress can lead to mental and physical depression.
\end{abstract}

○ The Asian Society of Kinesiology and the Korea Academy of Kinesiology

\section{서 론}

스트레스는 신체에 주어진 위협적이고 흥분되는 상황 에서 신체적, 심리적으로 긴장감이 고조되는 현상이다. 장 시간 스트레스의 노출은 피로와, 행동능력감소로 이어져 불안 및 우울증 유사 증세를 보이게 된다(Sierles, Chen \& McFarland, 1983). 스트레스에 제한적으로 짧은 기간에 노 출되면 일시적 스트레스, 장기간 지속적으로 노출되면 만

*Correspondence: Heon Seok, Department of Biomedical Science, College of Science and Engineering, Jungwon University, Chungbuk Goesan Munmuro 85, MII 825, 367-805, Korea.

E-mail adress: heonseok@jwu.ac.kr
성적 스트레스라 하며 특히 일시적 스트레스는 정서적 혼 란과 일상생활의 활동력 저하, 심리적 탈진이 발생한다 (Carver, Scheier, \& Weintraub, 1989; Smith, 1986). 만성적 스 트레스에 노출 시 집중력 저하로 일의 능률감소, 운동 시 심한 피로감으로 인해 인지능력 저하 및 불안증과 우울증 을 증가 시키는 것으로 나타났다(Matheny, Aycock \& Pugh, 1986; Smith, 1986). 특히 지속된 스트레스는 우울증 및 외 상 후 스트레스 질환과 같은 정신 병리학적 질환의 위험 요소로 알려져 있다(Hayley, Merali, \& Anisman, 2003). 우울 증은 단순히 슬픈 감정이나 우울한 기분에서부터 지속적 인 상실감 및 무력감, 나아가서 자살기도를 포함한 정신 
병적 상태에 이르기까지 그 증상이 다양하며 인간의 정 신건강 진단에 중요한 지표로 간주된다(Miché, Hofer \& Voss, 2017). 이러한 우울증 및 불안증은 항우울제를 사용 하는 약물치료법과 운동을 통한 신체활동으로 치료가 가 능하며, 운동을 통한 항우울 치료는 약물처리법보다 우 울증 재발생 비율이 낮다(Babyak, Blumenthal \& Herman, 2000; Blumenthal, Babyak \& Moore, 1999; Fasting, 1982; Ross \& Hayes, 1988). 또한 우울증 치료에 널리 쓰이고 있는 항 우울제는 치료 효과를 보는데 장시간이 소요되며 또한 치료효과도 우울증 환자의 $50 \sim 60 \%$ 에서만 치료 효과를 보인다고 알려져 있다(Dulawa, Holick \& Gundersen, 2004; Duman \& Monteggia, 2006).

스트레스 해소를 위한 유,무산소 운동은 항우울 치료 에 사용되지만 그 중 유산소 운동은 우울증과 불안증 감 소에 효과적이고 스트레스를 받은 후에도 평상시 수준 으로 빨리 회복시킨다(Pacak \& Palkovits, 2001). 특히 트레 드밀 운동은 단기, 장기적인 실행을 통해 우울증 감소에 효과적이다. 트레드밀 운동의 강도는 트레드밀 속력, 기 울기 및 운동시간을 기준으로 저강도, 중강도, 고강도로 나뉘며 각 강도마다 다른 효과를 보인다(Mead, Morley \& Campbell, 2008).

규칙적인 저강도, 중강도 트레드밀 운동은 어린 쥐의 뇌에서 스트레스로 감소된 뇌의 중추 신경전달물인 5-hydroxytryptamine(5-HT)의 발현을 증가시켜 5-HT 기능장 애로 나타나는 우울증과 행동장애 등을 치료하는데 효과 적으로 나타났다 (Kim, 2008). 장기간(3개월 이상)의 규칙 적인 저.중강도의 유산소 운동은 해마의 부피를 증가시키 며 뇌의 인지기능을 담당하는 영역 간의 상호 연결성을 증 진시키는 것으로 확인 되었으며(Erickson \& Kramer, 2009; Ruscheweyh, Willemer \& Kruger, 2011), 또한 신경세포 수준 에서 유산소운동은 신경세포생성(neurogenesis)을 증가 시키는 효과적인 방법으로 뇌의 구조적 기능적 개선에 긍 정적인 영향을 미쳐 기억 및 인지기능 향상과 신경조직을 개선하여 뇌 가소성(Plasticity)을 향상시키는 것으로 확인 되었다(Fordyce \& Wehenr, 1993; Kempermann, Van \& Gage, 2000; Van, Kempermann \& Gage, 1999). 이와 관련한 운동 으로 유도될 수 있는 뇌 신경가소성 변화의 대표적인 성 장인자인 brain-derived neurotrophic factor (BDNF)의 작용 으로 하위 신호전달 경로에 있는 Protein kinase $\mathrm{B}(\mathrm{PKB})$ 와 Extracellular signal-Regulated Kinase(ERK)의 활성을 조절 한다(Revest, Roux \& Roullot-Lacarrièreet, 2014). 또한 ERK
의 활성화는 뇌의 해마에서 스트레스로 활성화된 c-AMP response element binding(CREB)를 통해 c-fos 발현을 증가 시키며 mitogen-activated protein kinases(MAPK)의 신호전 달을 유도하는 일시적인 생리학적 스트레스의 원인 분자 로 보고되고 있다 (Ferrer, Friguls \& Dalfó, 2003).

본 연구는 선행연구에서 제시된 불안증, 우울증 완화 와 뇌의 가소성 및 인지기능 강화에 효과가 있는 중강도 운동을 스트레스를 받은 직후에 실행하여 이를 해소하고 자하는 방법이 효과적인지 알아보기 위해 Rat 을 이용하 여 감금스트레스 처치 직후 중강도 트레드밀 운동을 실시 에 따른 운동능력, 불안감, 우울감의 변화와 신경세포 내 의 중요 스트레스 관련 단백질인 $\mathrm{ERK}$ 의 활성변화를 분석 하여 스트레스 완화 효과를 확인하고자 하였다.

\section{연구 방법}

\section{연구대상}

본 연구에 사용된 6주령의 Rat은 대한바이오링크 (Daehan Biolink Inc, Korea)에서 구입하여 12시간의 주 - 야간 주기 (주간주기, 오전 8 시-오후 8 시), 온도 $23^{\circ} \mathrm{C} \pm 2{ }^{\circ} \mathrm{C}$ 습 도 $50 \%$ 에서 사육하였다. 실험기간 동안 항균 처리된 사료 (Purina Mills, Korea)와 수분섭취는 제한 없이 공급하였으 며, 실험의 모든 동물의 처치는 corticosterone 농도의 주간 변화에 의해 발생하는 실험의 불일치를 막기 위해 오전 9 시에서 오후 2시 사이에 진행하였다. 모든 실험은 Korean Academy of Medical Science(KAMS)의 권장사항에 따라 진 행하였다.

\section{실험설계 및 절차}

트레드밀 운동과 감금스트레스 효과를 조사하기 위하 여 집단은 대조군 그룹(CT), 감금스트레스 그룹(RS), 감금 스트레스 후 트레드밀 운동 그룹(EX)으로 각 15마리씩 구 분하였다. RS그룹은 투명 아크릴로 구성된 restrainer(지 름 $5 \mathrm{~cm}$ x 길이 $20 \mathrm{~cm}$ )에 rat을 최소한의 핸들링을 통해 넣 고 restrainer 선단에서 큰 호흡 구멍을 통하여 충분히 환기 를 제공하였다. 앞「뒤「상「하의 움직임을 제한하여 하루 1 시간씩 7일 동안 적용하였다. $\mathrm{EX}$ 그룹은 감금스트레스 적 용 1 시간 뒤 즉시 트레드밀을 이용한 지구성 운동을 실시 하였다. 운동 강도는 경사도를 $0 \%$ 로 고정시킨 상태에서 30 분 동안 $13 \mathrm{~m} / \mathrm{min}$ 의 중강도 운동으로 7일간 실시하였 다(Kim, 2008). 운동 시 뇌신경 변화에 영향을 주는 스트 


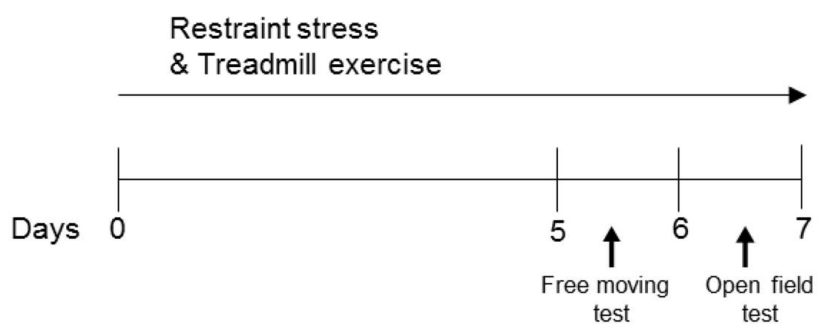

Figure 1. Time schedule of the Animal handling and behavior test

레스를 최소화하기 위해 전기 자극은 사용하지 않으며, 매일 감금 스트레스 전 몸무게를 측정하였다. 행동검사는 감금스트레스 직후와, 감금스트레스 후 트레드밀 운동 직 후에 실시하였다(Figure 1).

\section{Free Moving Test}

불투명 벽 $(35 \mathrm{~cm})$ 으로 둘러싸인 개방영역 $(80 \times 80 \mathrm{~cm})$ 에 $\mathrm{CT}, \mathrm{RS}, \mathrm{EX}$ 실험군 rat을 즉시 넣고 10 분 동안 행동을 video camera로 촬영하였으며, 촬영된 영상은 실시간으로 EthoVision system(Noldus 11.5ver, Netherlands)과 연동하여 1 분 간격으로 rat의 이동속력을 측정하고 10 분 동안 rat의 freezing 된 시간을 분석하였다. 테스트를 마친 뒤 개방영 역은 $70 \%$ 의 에틸알코올로 세척한 뒤 다음 실험군 테스트 를 진행하였다.

\section{Open Field Test}

대조군 및 감금스트레스와 트레드밀 운동을 7일째 수 행한 Rat을 움직이기 충분한 사각형 모양의 개방된 상자 $(80 \times 80 \times 35 \mathrm{~cm})$ 의 중심에 올려놓고 10 분 동안 환경을 탐 구하게 하였으며 실험동물의 일반운동 활성을 측정하 기 위해 EthoVision system을 활용하여 rat의 이동 경로를 추적하고 필드 중앙의 $60 \times 60 \mathrm{~cm}$ 영역을 중심부(central zone)로 설정한 뒤 중심부의 이동횟수, 이동거리, 속도를 분석하였다. 스트레스 자극 또는 트레드밀 운동 직후에 행동검사를 실시하였다.

\section{Western Blot Analysis}

행동실험을 마친 rat의 뇌에서 해마를 적출 한 후 $\mathrm{ERK}$ 단백질의 인산화 정도를 분석하였다. 적출 된 해마를 PBS로 3회 세척 후, Lysis buffer(50 mM Tris HCl pH 7.4, 1\% NP-40, $150 \mathrm{mM} \mathrm{NaCl}, 5 \mathrm{mM} \mathrm{MgCl}, 2.5$ mM EDTA pH8.0)
에 넣고 초음파 분쇄기로 30 초간 분쇄 후 15 분간 얼음에 유지한 뒤 $4^{\circ} \mathrm{C}$ 에서 $1000 \mathrm{~g}$ 로 10 분간 원심 분리하여 crude brain fraction을 분리하고 bradford assay를 통하여 $20 \mu \mathrm{g}$ 씩 $10 \%$ SDS-Polyacrylamide gel에서 전기영동 하였다. PVDF membrane으로 단백질을 전이시킨 후, $5 \%$ Skim milk가 첨 가된 $1 \times \mathrm{TBST}$ 용액으로 30 분 동안 실온에서 blocking시킨 후, p-ERK Thr177/Thr160 (cell signaling, 1:1000), ERK(Santa Cruz, 1:1000), $\beta$-actin (abcam, 1:4000) 항체를 이용하여 4「 에서 8 시간 탐침 하였다. 이후 TBST 완충액으로 10 분간 5 회 세척 후 각 항체에 따른 2차 항체인 Mouse-HRP(Santa Cruz, 1:5000), Rabbit-HRP(Santa Cruz, 1:5000)를 상온에 서 1 시간 동안 반응 후 $\mathrm{TBST}$ 로 1 시간동안 4회 membrane 을 세척하였다. Enhanced Chemiluminescence (ECL) (Biosesang, Korea) 반응을 유도 한 후 CHemiDoc (Bio-Red, USA) 을 사용하여 이에 반응하는 단백질의 밴드를 분석하였다.

\section{자료처리}

본 연구에서 도출된 모든 측정 자료는 PC / SPSS(Ver$\operatorname{sion} 20.0)$ 프로그램을 이용하였다. 기술 통계학적 분석을 통해 측정된 각 집단의 평균 및 표준오차를 기술하고 각 그룹 간 비교를 위해 대응표본 T-test를 실시하였으며 통 계적 유의수준은 $\mathrm{p}<.05$ 로 설정하였다.

\section{결 과}

\section{집단 간의 체중 변화}

감금 스트레스 자극과 트레드밀 운동을 실시한 5일 동 안 각 그룹의 체중 변화를 측정하였다(Figure 2). 체중은 스트레스 처치 및 운동 실시 1 일째부터 5 일까지 모든 그 룹에서 고르게 증가하였으며 그룹 간 유의한 차이점을 보 이지 않아 단기간의 감금스트레스 및 중강도 운동은 실험 동물의 체중에는 영향이 없는 것으로 나타났다.

\section{급성스트레스 직후 중강도 운동에 의한 운동활동 감소}

각 그룹간 공포의 정서 변화를 반영하는 행동분석을 위하여 각 그룹간 Free moving test를 실행 하였다(figure 3). 행동검사 1 분후에는 세 그룹 간 유의한 차이를 보이지 않 았으나 2분경과 후부터 EX그룹의 이동속도가 CT그룹에 비하여 $82 \%$ 까지 유의하게 낮아지고 4 분후에 최대 $84 \%$ 까 지 낮아졌으며 RS그룹에 비하여 $69 \%$ 까지 유의하게 낮았 으며 그 차이가 유지되었다(p<.01) (Figure 3A). 


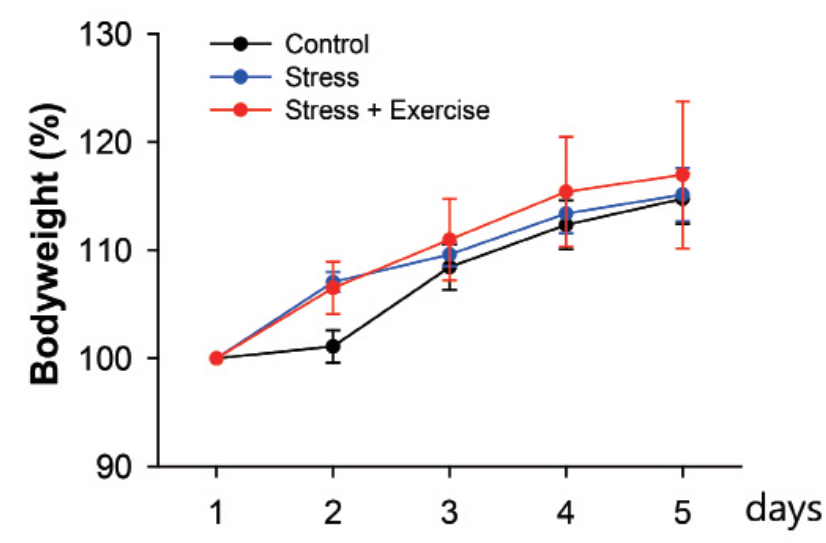

Figure 2. Analysis of weight change among each group

각 그룹의 이동거리를 나타낸 분석 결과는 CT그룹이 $\mathrm{EX}$ 그룹보다 실험시작 후 $1-2$ 분 사이에 최대 $85 \%$ 많이 이 동하였고 그 뒤로 10 분까지 유의하게 많이 이동하였으며 (p<.05), STRESS그룹보다 1 분에서 2 분 사이에 $20 \%$ 유의하 게 많이 이동한 것으로 나타났다(p<.01). EX그룹의 이동 거리가 2분후부터 급격히 떨어져 2-4 cm/sec로 유지되었 다(Figure 3B). Figure 3C는 각 그룹 실험군의 Freezing 시간 을 측정한 것이다. CT그룹 보다 RS그룹의 Freezing 시간 이 $83 \%$ 로 유의 하게 높았고 (p<.05), EX그룹은 RS그룹 $81 \%$ (p<.05), CT그룹보다 $164 \%$ ( $\mathrm{p}<.01)$ 유의 하게 늘어났다.

\section{급성스트레스 직후 중강도 운동에 의한 정서 상태 변화}

Open Filed Test를 통하여 CT, RS, EX그룹의 중심부 (Central Zone) 내로의 이동횟수, 거리, 속도를 분석하였다 (figure 4). (Figure 4B)는 중심부 내로의 이동횟수 나타내며 $\mathrm{RS}$ 그룹은 CT그룹 $45.3 \%$ 유의하게 낮았으며(p<.05). EX그 룹은 CT그룹보다 $70.3 \%$ 유의하게 낮았으나 RS그룹과는 유의한 차이를 보이지 않았다. 중심부에서 그룹간에 이동 거리 분석에서 RS그룹은 $\mathrm{CT}$ 그룹보다 중심부에서 이동한 거리가 $43 \%$ 유의하게 낮은 활동량을 보였다(p<.05). EX그 룹은 RS그룹보다 중심부에서 이동한 거리가 $35 \%$ 유의하 게 낮은 활동량을 보였다(p<.05) (Figure 4C). 중심부 내에 서의 평균 이동속도 분석결과 $\mathrm{EX}$ 그룹은 $\mathrm{CT}$ 그룹과 $71 \%$, $\mathrm{RS}$ 그룹보다 $63 \%$ 의 유의하게 낮은 평균 이동속도를 보였 다 $(\mathrm{p}<.01)$ (Figure $4 \mathrm{D})$.

\section{뇌의 해마에서 ERK의 인산화 변화}

행동분석 종료 후 각 그룹의 뇌에서 해마를 적출하여
(A)
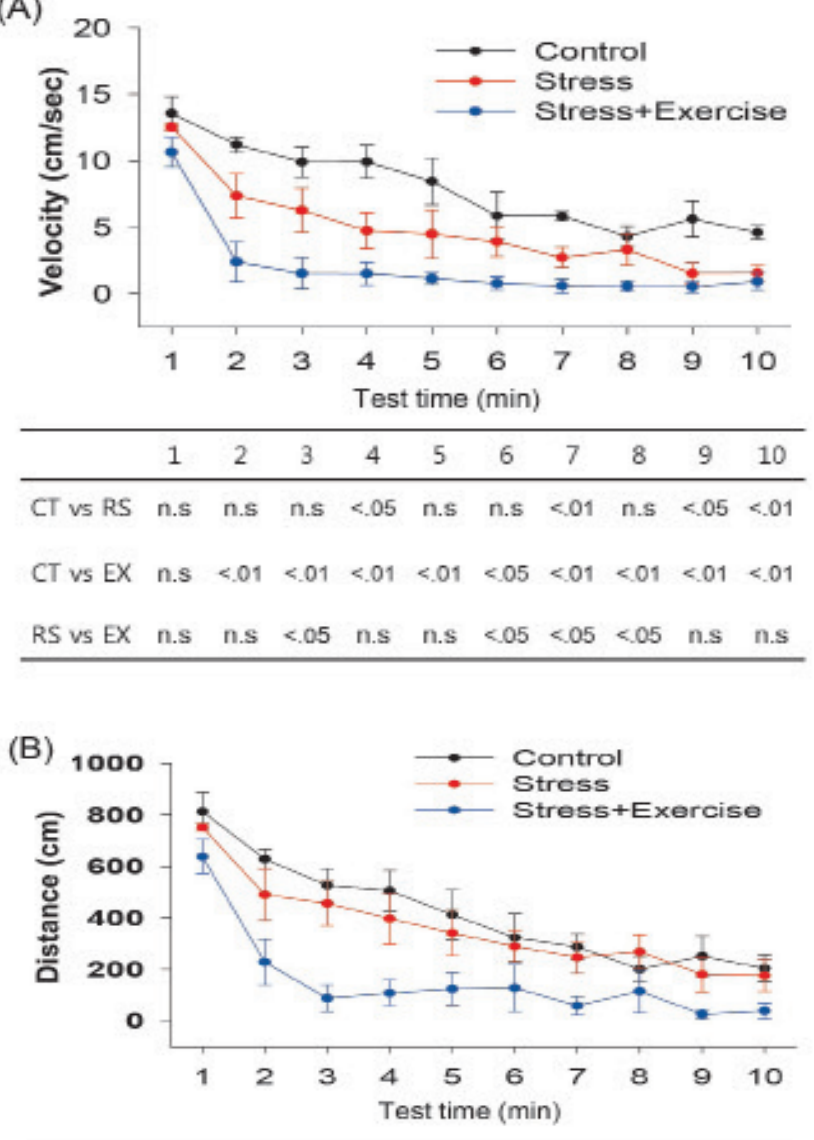

\begin{tabular}{lcccccccccc}
\hline & 1 & 2 & 3 & 4 & 5 & 6 & 7 & 8 & 9 & 10 \\
\hline CT vs RS n.s & n.s & n.s & n.s & n.s & n.s & n.s & n.s & n.s & n.s \\
CT vs EX n.s & $<.01$ & $<.01$ & $<.01$ & $<.05$ & n.s & $<.01$ & n.s & $<.05$ & $<.05$ \\
RS vs EX n.s & n.s & $<01$ & $<.05$ & n.s & n.s & $<.05$ & n.s & $<.05$ & n.s \\
\hline
\end{tabular}

(C)
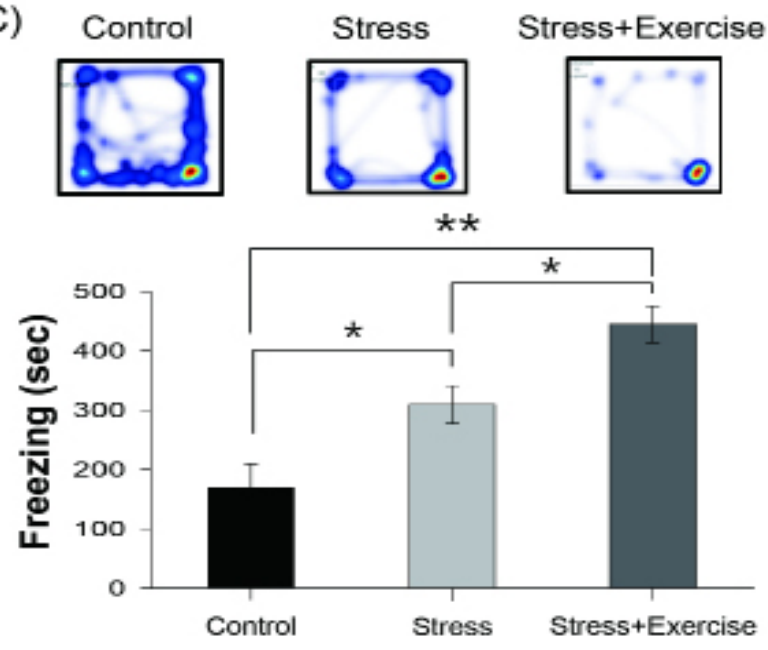

Figure 3. Analysis of free moving test. Velocity (A), Distance (B), Freezing times (C). 
(A)
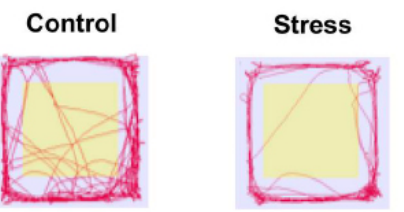

Stress+Exercise

Peripheral Zone Central Zone

(B)

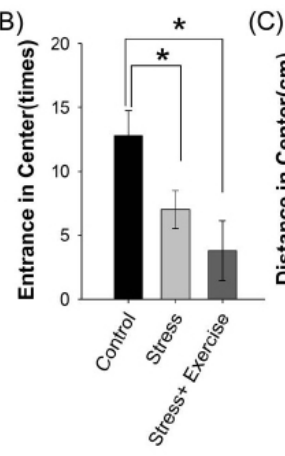

(C)
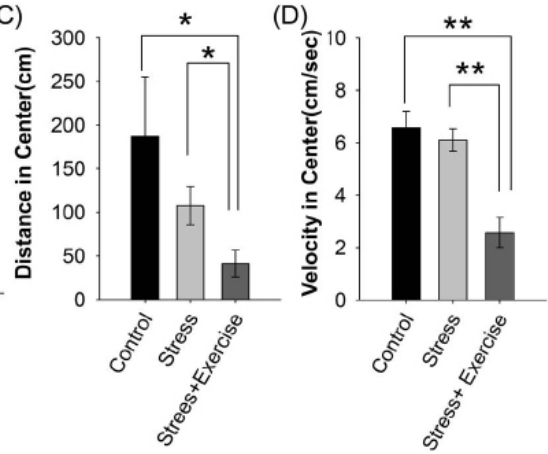

Figure 4. Analysis of center zone movement on open field test. Moving route(A), number of entrances (B), Distance (C), Velocity (D).

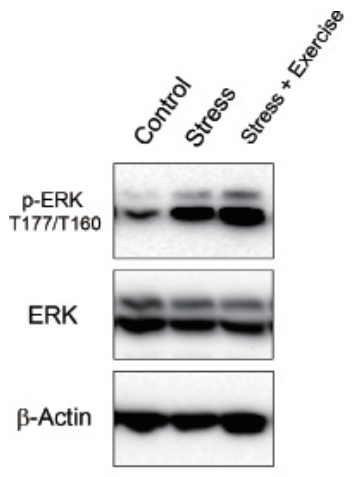

Figure 5. Phosphorylation of pERK thr177/thr160 in brain hippocampus.

western blot을 통해 CT그룹, RS그룹과 EX그룹간의 pERK thr177/thr160 의 phosphorylation 정도를 비교 분석하였다. ERK phosphorylation이 CT그룹에 비해 RS그룹이 $165 \%$ 유 의하게 높았으며 ( p<.01) EX그룹은 CT그룹보다 $292 \%$ 높 게 나타났다 $(\mathrm{p}<.01)$.

\section{논 의}

스트레스는 만성질환의 원인으로 현대사회의 질병 중 $50 \sim 70 \%$ 와 관련이 있으며, 심장병 유발요인의 $75 \%$ 를 차지 한다(Oh, Choi \& Kim, 1998; Pacak \& Palkovits, 2001). 본 연 구는 이러한 만성질환의 시작점이 될 수 있는 급성 스트 레스 조건에서 스트레스 직후 휴식기 없이 진행하는 중
강도 트레드밀 운동이 정서 및 운동기능에 미치는 영향 을 확인하였다.

본 연구를 통하여 적용된 1시간(일)-7일간의 감금스트 레스는 각 실험군 간의 체중변화가 유의한 차이점을 보 이지 않은 급성 스트레스를 조건에서 진행되었음을 우선 입증하였다.

Free moving test의 freezing 행동은 동물의 두려움과 불 안을 나타내는 행동으로 시간이 길수록 두려움과 불안 수 치가 높게 나타난다(Fasting, 1982; Greenwood, Foley \& Day, 2003; Moraska, Deak \& Spencer, 2000). 본 연구의 급성스트 레스 조건에서의 중강도 운동이 생리적 기능을 저하 시켜 활동량 감소 현상을 확인 하였으며, 또한 Freezing 시간을 더욱 증가시켜 급성 스트레스를 악화 시키고 불안증과 우 울증이 증가될 수 있는 있다는 것을 확인하였다.

급성 스트레스 조건에서 접근 회피 동작을 통하여 불 안감과 우울증의 증세를 파악 할 수 있는 Open field test (Christakis \& Ramirez, 2012)는 중심부에서의 활동 시간 이 탐험심 증가 또는 불안감 감소를 나타내고 새로운 환 경에 노출 되어 불안할 때 필드 주변부 벽에 기대어 나오 려 하지 않고 보호 받으려 한다(Christakis \& Ramirez, 2012; Dulawa, Holick \& Gundersen, 2004; Strekalova, Spanagel \& Dolgov, 2005). 급성 스트레스 직후에 중강도 운동을 하루 30 분씩 7일간 병행한 결과, 급성 스트레스에 중심부 회피 에 의한 불안증 및 우울증 유사 행동은 유의하게 증가하 였으며 행동능력은 유의하게 감소하여 급성 스트레스 직 후의 중강도 운동은 실험군에게 급성 스트레스를 가중 시킬 수 있게 작용한 것으로 나타났다.

이러한 급성스트레스로 일어나는 뇌 해마의 신경세포 활성을 알아보기 위하여 $\mathrm{ERK}$ 의 인산화 정도를 분석하였 다. ERK는 두려움과 공포감을 받으면 인산화가 증가하는 brain-derived neurotrophic factor(BDNF)의 하위 pathway 단 백질이다(Revest, Roux \& Roullot- Lacarrièreet, 2014). 스트 레스에 의한 뇌의 ERK 활성 증가는 dopamine 분비세포 의 활성 증가와 함께 $\mathrm{GABA}$ 분비세포의 활성을 억제시킴 으로써 불안증 및 우울증 유사 행동을 유도한다(Berton, McClung \& Dileone, 2006; Duman \& Monteggia, 2006). 급 성 스트레스로 인한 ERK의 인산화 증가는 선행연구를 통 하여 Rat의 nucleus accumbens(NAc)와 해마에서 확인되었 다(Leão, Cruz \& Marin, 2012). 본 연구에서의 적용된 급성 스트레스 실험군에서 ERK의 인산화 증가는 급성 스트레 스로 인한 불안감 우울 증세를 보인 선행 연구와 일치함 
을 확인하였다(Einat, Yuan \& Gould, 2003). 고강도 운동 후 에 ERK의 인산화 증가는 Brain-derived neurotrophic factor (BDNF)의 신호전달 경로를 통해 유도된다(Christakis \& Ramirez, 2012; Reichardt, 2006). 본 연구에서 급성 스트레 스 직후의 중강도 운동이 급성 스트레스만 받은 실험군보 다 증가된 ERK 인산화 결과를 나타낸 것은 중강도 운동이 고강도 운동과 같이 실험군에게 부정적 스트레스 유발 요 인으로 작용한 것으로 판단된다.

\section{결 론}

본 연구결과 첫째, 급성 스트레스 유발 직후의 중강도 운동이 실험동물의 체중에는 영향을 미치지 않는 것으로 나타났다. 둘째, 운동 활동의 지표인 이동거리 및 이동속 도가 감소하였다. 셋째, 불안/우울증 관련 행동의 지표인 중심부 이동횟수 및 시간이 감소하여 스트레스 증상을 해 소 하고자 실행하였던 중강도 운동이 오히려 운동 활동 저하 및 불안감 우울증의 증가 현상을 초래하였다. 또한 뇌의 해마에서 인지능력의 저해 요소인 $\mathrm{ERK}$ 의 인산화 증 가로 스트레스를 받은 직후 중강도 운동이 급성 스트레스 를 악화 시킬 수 있다는 것을 확인 하였다. 추후연구에서 는 스트레스 해소를 위한 중강도 운동의 실행 시점과 강 도를 파악하여 운동 활동 증가 및 불안 우울증을 극복할 수 있는 대체연구의 수행이 필요하다.

\section{Acknowlegdement}

이 논문은 2015년 정부(교육부)의 재원으로 한국연구재단 의 지원을 받아 수행된 연구임 (NRF-2013R1A1A4A01010683)

\section{Conflicts of Interest}

The authors declare no conflict of interest.

\section{References}

Babyak, M., Blumenthal, J. A., Herman, S., Khatri, P., \& Doraiswamy, M. (2000). Exercise treatment for major depression: maintenance of therapeutic benefit at 10 months. Psychosomatic Medicine, 62(5), 633-638.

Berton, O., McClung, C. A., Dileone, R. J., Krishnan, V., \& Renthal, W.
(2006). Essential role of BDNF in the mesolimbic dopamine pathway in social defeat. Stress Science, 311(5762), 864-868

Blumenthal, J. A., Babyak, M. A., Moore, K. A., Craighead, W. A., \& Herman, S. (1999). Effects of exercise training on older patients with major depression. Archives of Internal Medicine, 159(19), 2349-2356.

Carver C. S, Scheier M. F., \& Weintraub J. K. (1989). Assessing coping strategies: a theoretical based approach. Journal of Personality and Social Psychology, 56, 267-283.

Christakis, D. A., Ramirez, J. S., \& Ramirez, J. M. (2012). Overstimulation of newborn mice leads to behavioral differences and deficits in cognitive performance Scientific Reports, 2, 546.

Craft, L., \& Perna, F. (2004). The benefits of exercise for the clinically depressed. Primary Care Companion to the Journal of clinical Psychiatry, 6(3), 104-111.

Duman, R. S., \& Monteggia, L. M. (2006). A neurotrophic model for Stress-related mood disorders Biological Psychiatry, 59(12), 1116-1127.

Dulawa, S. C., Holick, K. A., Gundersen, B., \& Hen, R. (2004). Effects of Chronic Fluoxetine in Animal Models of Anxiety and Depression. Neuropsychopharmacology, 29(7), 1321-1330.

Einat, H., Yuan, P., Gould, T. D., Li, J., \& Du, J. (2003). The role of the extracellular signal-regulated kinase signaling pathway in mood modulation. Journal of Neuroscience, 23(19), 73117316.

Erickson, K. I. \& Kramer, A. F. (2009). Aerobic exercise effects on cognitive and neural plasticity in older adults. British Journal of Sports Medicine, 43, 22-24.

Fasting, K. (1982). Leisure Time Physical activity and some indices of mental health. Scandinavian Journal of Social Medicine, 29, 113-119.

Ferrer, I., Friguls, B., Dalfó, E., \& Planas, A. M. (2003). Early modifications in the expression of mitogen-activated protein kinase (MAPK/ERK), stress-activated kinases SAPK/JNK and p38, and their phosphorylated substrates following focal cerebral ischemia. Acta Neuropathologica, 105(5), 425-437.

Fordyce, D. E., \& Wehner, J. M. (1993). Physical activity enhances spatial learning performance with an associated alteration in hippocampal protein kinase $\mathrm{C}$ activity in C57BL/6 and DBA/2 mice Brain Research, 619(1-2), 111-119.

Greenwood, B. N., Foley, T. E., Day, H. E., Campisi, J., \& Hammack, S. 
H. (2003). Freewheel running prevents learned helplessness / behavioral depression: role of dorsal raphe serotonergic neurons. Journal of Neuroscience, 23(7), 2889-2898.

Hayley, S., Merali, Z., \& Anisman, H. (2003). stress and cytokine-elicited neuroendocrine and neurotransmitter sensitization Implication for depressive illness. Stress. 6, 19-32.

Kempermann, G., van Praag, H., \& Gage, F. H. (2000). Activity-dependent regulation of neuronal plasticity and self repair. Progress in Brain Research, 127, 35-48.

Kim, E. K. (2008). Effect of postnatal treadmill running on the serotonin expression in the raphe nuclei of rat pups born from the maternal rats exposed to noise during pregnancy. The Korea Journal of Sports Science, 17(4), 1157-1168.

Leão, R. M., Cruz, F. C., Marin, M. T., \& Planeta, Cda. S. (2012). Stress induces behavioral sensitization, increases nicotine-seeking behavior and leads to a decrease of CREB in the nucleus accumbens. Pharmacology Biochemistry and Behavior, 101(3), 434-442.

Matheny K. B., Aycock D. W., \& Pugh J. L., (1986). Stress Coping: a Qualitative and quantitative synthesis with implications for treatment. The Counseling Psychologist, 14, 499-549.

Mead G. E, Morley W, Campbell P, Greig C. A., McMurdo M., \& Lawlor D. A., (2008). Exercise for depression. The Cochrane Database of Systematic Reviews. 8(4), 121-129.

Miché, M., Hofer, P. D., Voss, C., Meyer, A. H., Gloster, A.T., Beesdo-Baum, K., Lieb, R, (2017). Mental disorders and the risk for the subsequent first suicide attempt: results of a community study on adolescents and young adults. European Child \& Adolescent Psychiatry. 219(26), 135-143.

Moraska, A., Deak, T., Spencer, R. L., Roth, D., \& Fleshner, M. (2000). Treadmill running produces both positive and negative physiological adaptations in Sprague-Dawley rats. American Journal of Physiology Regulatory, Integrative and Comparative Physiology, 279(4): 1321-1329.

Oh, J. J., Choi, S. K., Kim, T. H., Kim, E. S., \& Oh, J. K. (1998). The relationship between stress and life styles in businessman. Journal of the Korean Academy of Family Medicine, 19(4), 394-404.

Pacak, K., \& Palkovits, M. (2001). Stressor specificity of central neuroendocrine responses: Implications for stress-related disorders. Endocrine Reviews, 22(4), 502-548.

Reichardt, L. F. (2006). Neurotrophin-regulated signalling pathways. Philosophical Transactions of the Royal Society B Biological Sciences. 361(1473), 1545-1564.

Revest, J. M., Le Roux, A., Roullot-Lacarrière, V., Kaouane, N., \& Vallée, M. (2014). BDNF-TrkB signaling through Erk1/2 MAPK phosphorylation mediates the enhancement of fear memory induced by glucocorticoids. Molecular Psychiatry, 19(9), 1001-1009.

Ruscheweyh, R., Willemer, C., Kruger, K., Duning, T., Warnecke, T., Sommer, J., Volker K., Ho, H. W., Mooren, F., Knecht, S. \& Floel, A. (2011). Physical activity and memory functions: and interventional study. Neurobiology of Aging, 32, 1304-1319.

Ross, C. E., \& Hayes, D. (1988). Exercise and psychologic well-being in the community. American Journal of Epidemiology, 127(4), 762-771.

Sierles, F. S., Chen, J-J., McFarland, R. E., \& Taylor, M. A. (1983). Posttraumatic stress disorder and concurrent psychiatric illness: a preliminary report. The American Journal of Psychiatry, 140, 1177-1179.

Smith, M. S. (1986). Evaluation and management of psychosomatic symptoms in adolescence. Clinical Pediatrics, 25(3), 131-135.

Strekalova, T., Spanagel, R., Dolgov, O., \& Bartsch, D. (2005). Stress-induced hyperlocomotion as a confounding factor in anxiety and depression models in mice. Behavior Pharmacology, 16(3), 171-180.

Van Praag, H., Kempermann, G., \& Gage, F. H. (1999). Running increases cell proliferation and neurogenesis in the adult mouse dentate gyrus. Nature Neuroscience, 2(3), 266-270. 